\title{
Chemical composition of the freshwater prawn Cryphiops caementarius (Molina, 1782) (Decapoda: Palaemonidae) in two populations in northern Chile: reproductive and environmental considerations
}

\author{
Jorge E. Moreno-Reyes ${ }^{1}$, Carlos A. Méndez-Ruiz ${ }^{1}$, Gina X. Díaz ${ }^{1}$ \\ Jaime A. Meruane ${ }^{2}$ \& Pedro H. Toledo ${ }^{2,3}$ \\ ${ }^{1}$ Programa de Magister en Acuicultura, Departamento de Acuicultura, Facultad de Ciencias del Mar \\ Universidad Católica del Norte, Larrondo 1281, Coquimbo, Chile \\ ${ }^{2}$ Departamento de Acuicultura, Facultad de Ciencias del Mar, Universidad Católica del Norte \\ Larrondo 1281, Coquimbo, Chile \\ ${ }^{3}$ Centro de Estudios Avanzados en Zonas Áridas, CEAZA, Coquimbo, Chile \\ Corresponding author: Jorge E. Moreno (jmr018@ucn.cl)
}

\begin{abstract}
Reductions of its natural populations have led to recent efforts in small-scale aquaculture of the freshwater prawn Cryphiops caementarius, either for conservation or commercial purposes. However, the lack of knowledge about its nutritional requirements has been one of the major obstacles for its successful culture. Given its importance, this study determines and compares the chemical composition (moisture, ash, crude protein, total lipids and nitrogen free extract) of whole animals and main storage tissues (gonad, hepatopancreas and muscle), of $C$. caementarius adult prawns from two natural populations. Moreover, the relation of this composition with reproductive and environmental parameters (sex, maturation and habitat) is discussed. The specimens were collected in Limarí and Choapa rivers (Coquimbo, Chile) during reproductive season, and divided into six categories according to capture location, gonad maturation stage, and gender. The chemical composition of whole animals and storage tissues was compared among categories. Significant differences were observed between tissues, sexes, maturity stages and locations. Regarding tissues, the muscle and the gonads were rich in protein, whereas the hepatopancreas had high lipid content. According to results, factors such as sex, habitat and stage of gonad maturation can modify the biochemistry of $C$. caementarius. Nonetheless, the main chemical variations were observed in tissues involved in regulatory processes (hepatopancreas and gonads), and to a lesser extent in structural tissues (muscle). This is the first study known that reports information about the biochemistry of $C$. caementarius and its findings may be useful to improve feeding practices in aquaculture.
\end{abstract}

Keywords: Cryphiops caementarius, chemical composition, nutritional requirements, protein, lipids, storage tissues.

Composición química del camarón de río Cryphiops caementarius (Molina, 1782) (Decapoda: Palaemonidae) en dos poblaciones del norte de Chile: consideraciones reproductivas y ambientales

\begin{abstract}
RESUMEN. El detrimento de las poblaciones naturales de Cryphiops caementarius ha conducido a un reciente esfuerzo para implementar actividades de acuicultura a pequeña escala con fines de repoblamiento y comerciales. Sin embargo, la falta de conocimiento de sus requerimientos nutricionales ha sido uno de los mayores obstáculos para el éxito de su cultivo. Dada su importancia, este estudio determina y compara la composición química (humedad, ceniza, proteína cruda, lípidos totales y extractos libres de nitrógeno) de animales enteros y tejidos (gónada, hepatopáncreas y músculo) de especímenes adultos de C. caementarius provenientes de dos poblaciones naturales. Los animales fueron capturados en los ríos Limarí y Choapa (Coquimbo, Chile) durante su estación reproductiva natural y organizados en seis categorías de acuerdo al sexo, estado de madurez gonadal y lugar de captura. Se determinaron diferencias significativas entre tejidos, sexos, estados de madurez y lugares de captura. Con respecto a los tejidos, los valores más altos de proteína se encon-
\end{abstract}

Corresponding editor: Luis Miguel Pardo 
traron en el músculo y la gónada, mientras que los de lípidos se encontraron en el hepatopáncreas. De acuerdo a los resultados obtenidos, factores como el sexo, estado de madurez gonadal y lugar de procedencia de los animales, pueden modificar la composición química de $C$. caementarius. No obstante, la principales variaciones ocurren en tejidos involucrados en procesos regulatorios (gónada y hepatopáncreas) y en menor medida en tejidos estructurales (músculo). Este es el primer estudio de la composición química de C. caementarius, y sus resultados podrían ser utilizados para mejorar las prácticas de alimentación en actividades de acuicultura.

Palabras clave: Cryphiops caementarius, composición química, requerimientos nutricionales, proteína, lípidos, tejidos de almacenamiento.

\section{INTRODUCTION}

Cryphiops caementarius (Molina, 1782) commonly known in Chile as the northern river prawn, is one of the most important freshwater resources and the only species of the Palaemonidae family present in Chilean inland waters (Jara et al., 2006; Meruane et al., 2006). However, indiscriminate extraction due to its economic importance and the human alterations of its habitat, have reduced its natural populations, putting this species in danger of extinction for some locations within its natural distribution range (Jara et al., 2006).

The damage caused to the northern river prawn, has encouraged researchers to investigate the biology and the culture requirements of the species (Castro, 1966; Bahamonde \& Vila, 1971; Norambuena, 1977; Viacava et al., 1978; Rivera \& Meruane, 1994), with the aim of establish artificial culture systems that allow to reduce the extractive pressure over the resource and recover its natural populations. Nevertheless, the difficulty to satisfy its environmental requirements in captivity due to its complex life cycle, along with high mortality rates during ecdysis, high cannibalism behavior during mating season and other issues commonly related with nutritional deficiencies (e.g., low reproductive performance) has delayed the successful culture of $C$. caementarius under controlled conditions.

Since chemical composition analysis is considered an appropriate way to gather information about the nutritional requirements in crustaceans, many researchers have conducted investigations to understand how different organs store and transfer nutrients to support physiological events such as growth (HernándezVergara et al., 2003), reproduction (Pillay \& Nair, 1973; Castille \& Lawrence, 1989; Cavalli et al., 1999; Palacios et al., 2000; Wen et al., 2001; Rosa \& Nunes, 2002; Rodríguez-González et al., 2006) and maintenance (Rosa \& Nunes, 2003; Oliveira et al., 2007; Vinagre et al., 2007). However, regarding the biochemistry of crustaceans, it has been stated that environmental factors such as habitat, food availability, and seasonality can modify their metabolism (Schirf et al., 1987; Kucharski \& Da Silva, 1991; Oliveira et al.,
2003), and thus their chemical composition (Rosa \& Nunes, 2003).

Because there are no formal studies focused on the biochemistry of $C$. caementarius, the objective of the present work was to determine the chemical composition of adult male and female prawns from two natural populations, and to evaluate the influence of environmental and reproductive factors on the accumulation of nutrients in main storage tissues. As the knowledge of nutritional requirements in decapods has been considered crucial to their successful culture in captivity, the aim of this investigation was to determine basic nutritional requirements of the species, in order to improve small-scale aquaculture practices as an alternative way to recovering natural populations. Study of this species is important because of its social and economic importance (Meruane et al., 2006), and its conservation status which is reported as vulnerable to critically endangered according to Jara et al. (2006) and vulnerable according to the agreement 6/2014 included into the species conservation status list, published by the ministry of environment of Chile.

\section{MATERIALS AND METHODS}

All live animals utilized in this research were treated with proper care, minimizing discomfort and distress. Also, the number of sampled animals was kept to the minimum necessary to obtain scientific results, balancing the gain in knowledge with the long-term conservation and well-being of the species. The animals were used with the permission of the Ethic and Biotechnology Committee of the Universidad Católica del Norte, Chile.

\section{Biological material}

Adults of C. caementarius (cephalotorax length $>14.3$ $\mathrm{mm}$ according to Bahamonde \& Vila, 1971) were extracted from Choapa $\left(31^{\circ} 39^{\prime} 85^{\prime \prime} \mathrm{S}, 71^{\circ} 9^{\prime} 17^{\prime \prime} \mathrm{W}\right)$ and Limarí $\left(30^{\circ} 39^{\prime} 26^{\prime \prime} \mathrm{S}, 71^{\circ} 31^{\prime} 13^{\prime \prime} \mathrm{W}\right)$ rivers (Coquimbo, Chile) between October 2009 and February 2010 (high reproductive activity), and then carried alive to the crustaceans laboratory of the Universidad Católica del 
Norte in Coquimbo, Chile. 20 males in stage III (mature), 48 females in stage I (immature) and 20 females in stage IV (advanced maturity) of gonadic development, along with 20 males in stage III, 50 females in stage I and 20 females in stage IV, extracted from Choapa and Limarí rivers, were utilized for the analysis of chemical composition. All animals were intermolt hard-shelled and stages of gonadic maturation were visually identified based on size, color and gross morphology according to the scale proposed by Viacava et al. (1978). In the laboratory, the prawns were divided into six categories according to their capture location, maturation stage and gender (Table 2). Prawns were then place in water and kept in to the fridge $\left(4^{\circ} \mathrm{C}\right)$ during $1 \mathrm{~h}$ to decrease their metabolism before being euthanized. Immediately after, some prawns were conserved intact for the chemical analysis in whole animals and the others were dissected to remove the gonads, the hepatopancreas, and the abdominal muscle. Tissues were individually weighed and pooled from six to eight individuals when there was insufficient amount to perform all analyses (e.g., immature female gonad). Subsequently, tissue samples and whole animals were kept in plastic bags covered with aluminum foil and maintained at $-20^{\circ} \mathrm{C}$ until their chemical analysis (two weeks maximum).

\section{Chemical composition}

Moisture, ash, crude protein and total lipid contents of gonad, hepatopancreas, abdominal muscle, and whole animals were determined by triplicate according to the AOAC (1995). The moisture was obtained by oven drying at $95^{\circ} \mathrm{C}$ to constant weight. Ash was quantified after calcination in muffle furnace at $550^{\circ} \mathrm{C}$. Crude protein was determined using the Kjeldahl method, with a conversion factor of 6.25. Total lipids were determined using the Soxhlet method. Nitrogen free extract (NFE) was calculated with the formula: NFE = 100 - (crude protein $\%+$ total lipids $\%+$ ash \%) in accordance with Tacon (1989). The number of samples used for analysis of whole animals and tissue was $\mathrm{n}=$ 10 except for gonad tissue of LIF and CIF where the number of samples was $n=5$.

\section{Statistical analysis}

Differences in the chemical composition of tissues analyzed and whole animals between categories (LIF, LMF, LMM, CIF, CMF and CMM) were tested with a one-way analysis of variance (one-way ANOVA) followed by a multiple-comparison test (Holm-sidak) as needed. Whenever necessary, data were transformed to satisfy normal distribution and homoscedasticity requirements. The data reported as percentages were transformed to arcsine values prior to analysis (Sokal \& Rohlf, 1981). All statistical analyses were tested at the
0.05 level of probability with the software Sigma Stat 3.1 for Windows.

\section{RESULTS}

The chemical composition of whole animals and main storage tissues of $C$. caementarius is presented in Table 1. Significant differences were detected between tissues, sexes and locations (Table 1). Regarding whole animals, females had higher values of crude protein and total lipids than males, but low ash content independently of the stage of maturation and capture location. Concerning tissues, the highest values of moisture were found in abdominal muscle of the six prawn categories (75.54-77.72\%), and gonadal tissue of CIF (74.93\%), LIF (75.08\%), LMM (79.58\%) and CMM $(80.10 \%)$. Independently of capture location, immature females had higher moisture levels in the gonads (approximately 30\%) than mature females.

In male and female prawns from both rivers, and independently of the stage of maturation, the muscle and the gonads were rich in protein, whereas the hepatopancreas had high lipid content. The highest values of protein in tissue were found in abdominal muscle for the six categories ranging from 83.18 to $85.48 \%$. Concerning sexes, muscle of $C$. caementarius males had significantly more protein content than females (Table 1). In relation to location, animals from Choapa River had generally more protein content in abdominal muscle than animals from Limarí River.

Independently of location, sex, or stage of maturation, proteins were the most abundant component in gonads (50.05-74.28\%), followed by lipids (16.73-36.08\%) and NFE as minor component (0.85$14.10 \%)$. In contrast, in the case of the hepatopancreas, lipids were the most abundant component (63.53$72.41 \%)$, followed by proteins $(16.34-22.02 \%)$ and NFE (3.20-18.07\%).

Contrary to the slight sex and location differences observed in the chemical composition of abdominal muscle, the variations in the chemical composition of the gonads and the hepatopancreas showed a remarkable relation with sex, stage of maturation and capture location (Table 1). In the case of Limarí River, mature female prawns showed higher protein and lipid levels in the gonads than immature female prawns, whereas in the hepatopancreas, the higher protein and lipid levels were found in immature females instead of in mature females. The same results were observed in prawns from Choapa River, except for the hepatopancreas of mature females, where the lipid levels were higher than those of immature females. In addition, regarding mature animals, males from both Limarí and Choapa rivers had higher protein levels in gonads than 
Table 1. Cryphiops caementarius broodstock, chemical composition in whole animals and tissues, from Limarí and Choapa rivers. Values are the mean \pm standard deviation expressed as percentage dry weight. Means in a row sharing different superscript letters were significantly different $(P<0.05)$. The number of samples for whole animals and tissue analysis in all categories was $n=10$, except for gonad tissues of LIF and CIF where the number of samples for all chemical analysis was $\mathrm{n}=5$. LIF: Limarí immature female, LMF: Limarí mature female, LMM: Limarí mature male, CIF: Choapa immature female, CMF: Choapa mature female, CMM: Choapa mature male, NFE: Nitrogen free extract.

\begin{tabular}{|c|c|c|c|c|c|c|}
\hline & LIF & LMF & LMM & CIF & $\mathrm{CMF}$ & CMM \\
\hline \multicolumn{7}{|l|}{ Whole animal } \\
\hline Moisture & $70.91 \pm 0.11^{\mathrm{e}}$ & $65.29 \pm 0.15^{\mathrm{b}}$ & $58.06 \pm 0.17^{\mathrm{a}}$ & $70.21 \pm 0.28^{\mathrm{d}}$ & $66.73 \pm 0.21^{\mathrm{c}}$ & $71.58 \pm 0.22^{\mathrm{f}}$ \\
\hline Ash & $17.65 \pm 0.17^{\mathrm{c}}$ & $19.42 \pm 0.05^{\mathrm{d}}$ & $25.91 \pm 0.23^{\mathrm{e}}$ & $17.25 \pm 0.23^{b}$ & $13.81 \pm 0.18^{\mathrm{a}}$ & $28.61 \pm 0.20^{\mathrm{f}}$ \\
\hline Crude protein & $60.63 \pm 0.18^{\mathrm{d}}$ & $61.20 \pm 0.19^{\mathrm{e}}$ & $55.32 \pm 0.10^{b}$ & $60.27 \pm 0.26^{c}$ & $63.32 \pm 0.16^{\mathrm{f}}$ & $53.58 \pm 0.09^{\mathrm{a}}$ \\
\hline Total lipids & $21.49 \pm 0.01^{\mathrm{e}}$ & $19.26 \pm 0.15^{\mathrm{c}}$ & $15.22 \pm 0.19^{\mathrm{a}}$ & $20.08 \pm 0.22^{\mathrm{d}}$ & $21.25 \pm 0.25^{\mathrm{e}}$ & $17.52 \pm 0.19^{\mathrm{b}}$ \\
\hline NFE & 0.23 & 0.12 & 3.55 & 2.40 & 1.62 & 0.29 \\
\hline \multicolumn{7}{|l|}{ Gonads } \\
\hline Moisture & $75.08 \pm 0.09^{\mathrm{c}}$ & $44.42 \pm 0.01^{\mathrm{b}}$ & $79.58 \pm 0.09^{\mathrm{d}}$ & $74.93 \pm 0.12^{\mathrm{c}}$ & $42.86 \pm 0.04^{\mathrm{a}}$ & $80.10 \pm 0.11^{\mathrm{e}}$ \\
\hline Ash & $7.65 \pm 0.07^{c}$ & $2.79 \pm 0.01^{\mathrm{a}}$ & $7.08 \pm 0.07^{\mathrm{b}}$ & $7.60 \pm 0.05^{\mathrm{c}}$ & $2.92 \pm 0.18^{\mathrm{a}}$ & $7.27 \pm 0.07^{\mathrm{b}}$ \\
\hline Crude protein & $50.05 \pm 0.18^{\mathrm{a}}$ & $59.23 \pm 0.04^{c}$ & $70.04 \pm 0.19^{\mathrm{e}}$ & $51.07 \pm 0.71^{\mathrm{b}}$ & $60.15 \pm 0.10^{\mathrm{d}}$ & $74.28 \pm 0.11^{\mathrm{f}}$ \\
\hline Total lipids & $28.20 \pm 0.27^{\mathrm{c}}$ & $34.79 \pm 0.07^{\mathrm{e}}$ & $20.53 \pm 0.11^{b}$ & $28.68 \pm 0.02^{\mathrm{d}}$ & $36.08 \pm 0.11^{\mathrm{f}}$ & $16.73 \pm 0.15^{\mathrm{a}}$ \\
\hline NFE & 14.10 & 3.19 & 2.35 & 12.65 & 0.85 & 1.72 \\
\hline \multicolumn{7}{|l|}{ Hepatopancreas } \\
\hline Moisture & $48.92 \pm 0.04^{\mathrm{d}}$ & $43.35 \pm 0.02^{b}$ & $45.77 \pm 0.05^{\mathrm{c}}$ & $49.34 \pm 0.17^{\mathrm{e}}$ & $39.19 \pm 0.25^{\mathrm{a}}$ & $57.66 \pm 0.22^{\mathrm{f}}$ \\
\hline Ash & $2.88 \pm 0.03^{\mathrm{e}}$ & $2.06 \pm 0.03^{b}$ & $2.06 \pm 0.05^{\mathrm{b}}$ & $2.48 \pm 0.06^{\mathrm{c}}$ & $1.60 \pm 0.05^{\mathrm{a}}$ & $2.64 \pm 0.06^{\mathrm{d}}$ \\
\hline Crude protein & $22.02 \pm 0.11^{\mathrm{f}}$ & $17.49 \pm 0.02^{c}$ & $16.34 \pm 0.18^{b}$ & $20.94 \pm 0.07^{e}$ & $16.11 \pm 0.08^{a}$ & $19.43 \pm 0.01^{\mathrm{d}}$ \\
\hline Total lipids & $71.90 \pm 0.23^{\mathrm{d}}$ & $63.67 \pm 0.19^{a}$ & $63.53 \pm 0.07^{\mathrm{a}}$ & $66.63 \pm 0.29^{b}$ & $72.41 \pm 0.23^{\mathrm{d}}$ & $71.00 \pm 0.23^{\mathrm{c}}$ \\
\hline NFE & 3.20 & 16.78 & 18.07 & 9.95 & 9.88 & 6.93 \\
\hline \multicolumn{7}{|l|}{ Muscle } \\
\hline Moisture & $76.55 \pm 0.18^{b}$ & $77.32 \pm 0.02^{\mathrm{bd}}$ & $77.72 \pm 0.07^{d}$ & $76.68 \pm 0.10^{\mathrm{c}}$ & $75.54 \pm 0.10^{\mathrm{a}}$ & $77.67 \pm 0.05^{\mathrm{d}}$ \\
\hline Ash & $5.56 \pm 0.08^{\mathrm{c}}$ & $5.58 \pm 0.03^{\mathrm{c}}$ & $5.82 \pm 0.05^{\mathrm{d}}$ & $5.43 \pm 0.04^{\mathrm{b}}$ & $5.08 \pm 0.04^{\mathrm{a}}$ & $5.81 \pm 0.05^{\mathrm{d}}$ \\
\hline Crude protein & $83.41 \pm 0.14^{\mathrm{a}}$ & $83.81 \pm 0.12^{\mathrm{bc}}$ & $84.06 \pm 0.04^{b}$ & $83.55 \pm 0.13^{\mathrm{ac}}$ & $83.18 \pm 0.07^{\mathrm{a}}$ & $85.48 \pm 0.25^{\mathrm{d}}$ \\
\hline Total lipids & $9.03 \pm 0.06^{\mathrm{b}}$ & $10.32 \pm 0.04^{\mathrm{d}}$ & $10.07 \pm 0.04^{\mathrm{cd}}$ & $9.88 \pm 0.05^{\mathrm{c}}$ & $11.39 \pm 0.05^{\mathrm{e}}$ & $8.50 \pm 0.06^{\mathrm{a}}$ \\
\hline NFE & 2.00 & 0.29 & 0.05 & 1.14 & 0.35 & 0.21 \\
\hline
\end{tabular}

females, but lower lipid levels (Table 1). With regard to the NFE content, independently of capture location, this was high in the gonads but low in the hepatopancreas and muscle of immature females, whereas in mature females, NFE levels were low in gonadal and muscle tissues and high in hepatopancreatic tissue.

\section{DISCUSSION}

The results presented in this work constitute the first report of the chemical composition in whole animals (males and females) and main storage tissues (gonads, hepatopancreas and muscle) of adult $C$. caementarius prawns. According to Dempson et al. (2004), the proximate body composition including moisture, fat, protein and ash are good indicators of physiological condition of an organism. The greater the protein and lipid content represents higher the energy density. Despite the significant differences detected between tissues, sexes and locations, the high protein levels found during this study in both whole animals (from 53.58 to $63.32 \%$ ) and abdominal muscle tissue (from 83.18 to $85.48 \%$ ) of C. caementarius, suggest a good physiological condition of wild specimens (male and female) from Limarí and Choapa rivers and point this species as a remarkable source of protein for human consumption.

With regard whole animals, moisture levels in male and female C. caementarius prawns (58-71\%) were lower than the levels reported in Macrobrachium rosenbergii (73.1-81.0\%) (Santos et al., 2007), whereas the ash contents were higher in C. caementarius (13.81$28.61 \%$ ) than in M. rosenbergii (2.0-4.1\%) (Santos et al., 2007). In the case of crude protein and total lipids, the mean levels in C. caementarius (Table 1) were higher than the levels reported for adult specimens of Macrobrachium jelskii (34-58\% and 9.8-11.3 respectively) by Ramirez et al. (2010), but lower than the levels reported for M. rosenbergii (73.2-78.0\% and $5.5-22.4 \%$ respectively) by Santos et al. (2007). In the 
Tabla 2. Categories of prawns according to their capture location, maturation stage and gender.

\begin{tabular}{lcc}
\hline Categories of prawns & $\begin{array}{c}\text { Cephalothorax } \\
\text { length } \pm \text { SD }(\mathrm{mm})\end{array}$ & $\begin{array}{c}\text { Wet } \\
\text { weight } \pm \mathrm{SD}(\mathrm{g})\end{array}$ \\
\hline Limarí immature female (LIF) & $41.17 \pm 4.06$ & $49.55 \pm 8.76$ \\
Limarí mature female (LMF) & $41.86 \pm 4.72$ & $52.21 \pm 9.08$ \\
Limarí mature male (LMM) & $59.80 \pm 2.49$ & $143.49 \pm 20.47$ \\
Choapa immature female (CIF) & $41.12 \pm 4.46$ & $51.65 \pm 6.80$ \\
Choapa mature female (CMF) & $42.21 \pm 5.66$ & $55.90 \pm 11.12$ \\
Choapa mature male (CMM) & $61.41 \pm 5.50$ & $160.52 \pm 23.15$ \\
\hline
\end{tabular}

case of NFE, the levels from 0.12 to $3.55 \%$ found in $C$. caementarius were similar to other palaemonids like $M$. rosenbergii (0.2-19.4\%; Santos et al., 2007) and $M$. jelskii (0.6-3.4\%; Ramirez et al., 2010).

In relation to the differences in the chemical composition between whole males and females, in general terms males had higher ash levels than females but lower protein and lipid levels (Table 1). These differences in the proportions of nutrients between sexes could be associated with reproductive aspects. According to Rojas et al. (2012) C. caementarius mature males fight aggressively during mating season for access to reproductive females, causing superficial marks and puncture/crack injuries mainly on the chelipeds. Based on this reproductive behavior, we suggest that as occurs in other freshwater decapods, such as Procambarus clarkii, where chelae were more heavily mineralized than branchiostegites, and Astacus astacus where statistical differences were detected between sexual active and inactive animals regarding the concentration of mineral matter in both chelae and branchiostegites (Huner \& Lindqvist, 1985), mature males of $C$. caementarius may increase shell hardness and thickness by an increase in shell calcification, in order to reduce possible injuries during intrasexual combats. As a result of this strategy, the mineral content in males increases with regard to females. Therefore, the ash levels rise while the levels of the others nutrients decrease. The presence of a large number of robust spines in male chelipeds reported by Rojas et al. (2012) which implies an increase in calcium fixation supports this suggestion.

Regarding storage tissues, abdominal muscle had the highest levels of protein and the lowest levels of NFE. Protein levels in muscle $(83-85 \%)$ were higher than others palaemonids such as $M$. rosenbergii (73$78 \%$ ) (Santos et al., 2007) and M. carcinus $(74-77 \%)$ (Benítez-Mandujano \& Ponce-Palafox, 2014), and similar to commercial crayfishes such as A. astacus (83.6-84.9\%) and P. clarkii (80.7-86.8\%) (Huner et al., 1988). Although proteins can be also accumulated in the hepatopancreas and the gonads, the high levels found in abdominal muscle confirm this tissue as the main protein-storage location in $C$. caementarius. Concerning sexes, $C$. caementarius males had more protein content in muscle than females (Table 1). The same result has been reported by Huner et al. (1988) in $A$. astacus and $P$. clarkii. In addition, animals from Choapa River (male and female) had generally more protein content in abdominal muscle in comparison to animals from Limarí River.

Some studies in crustaceans had reported that protein levels in whole animals (Santos et al., 2007) and muscle tissues (Benítez-Mandujano \& Ponce-Palafox, 2014) can be influenced by protein levels in diet. Consequently the higher protein levels found in animals from Choapa River may be related to a wide variety and quality of food sources in this river, which is supported by the larger flora and fauna reported in Choapa River (SINIA, 2004a) when compared to Limarí River (SINIA, 2004b). The influence exerted by food (e.g., availability, quality and nutritional composition) over the chemical composition in crustaceans has also been investigated in natural conditions for Aristeus antennatus (Crustacea: Penaeidea), Parapenaeus longirostris (Crustacea: Penaeidea) and Nephrops norvegicus (Crustacea: Astacidea) by Rosa \& Nunes, (2002, 2003) and in culture conditions for M. jelskii by Ramírez et al. (2010) and Litopenaeus vannamei by Ezquerra-Brauer et al. (2003). These studies reported variations in protein, lipid and carbohydrate contents in relation to available diet.

In the case of total lipids in muscle, females had generally more contents than males, especially in animals from Choapa River. The higher levels of total lipids found in abdominal muscle of females in comparison to males, has also been reported in Cancer pagurus (Barrento et al., 2010) and M. rosenbergii (Saravana-Bhavan et al., 2010). In addition $C$. caementarius mature females had higher lipid levels in muscle than immature females. Compared with other species, C. caementarius had higher lipid levels in muscle than $M$. rosenbergii (3.7-7.3\%) (Cavalli et al., 2001), M. carcinus (5.1\%) (Benítez-Mandujano \& 
Ponce-Palafox, 2014) and Cancer pagurus (0.7-1.3\%) (Barrento et al., 2010). The higher lipid and protein levels found in abdominal muscle of animals from Choapa River in comparison to animals from Limarí River, may suggest that animals from Choapa River have a better physiological condition than animals from Limarí River. Concerning moisture and ash contents, $C$. caementarius males had higher levels in abdominal muscle than females (Table 1) as occurs in $M$. rosenbergii (Saravana-Bhavan et al., 2010).

Regarding both the gonads and the hepatopancreas, the high moisture content and low nutrient levels (crude protein or total lipids or NFE) found in immature females in comparison to mature females suggest that during ovarian cycle, these organs, and mostly the ovary, replace the water inside with nutrients for the vitellus. The same mechanism has been reported in Cherax quadricarinatus, where lipid and protein levels in the ovary increase during vitellogenesis while moisture levels decrease ( $\mathrm{Li}$ et al., 2010), and in Armases cinereum and Sesarma reticulatum where the lipid and carbon contents in the ovary increase throughout ovarian maturation, while water concentration decreases significantly (Hasek \& Felder, 2005). In addition, for all analyzed tissues, especially the gonads, high moisture levels were accompanied by high ash levels (Table 1). The levels of ash found in gonads (2.70-7.65\%), hepatopancreas (1.60-2.88\%) and abdominal muscle $(5.08-5.82 \%)$ of $C$. caementarius males and females, were high in comparison to the freshwater prawn Macrobrachium rosenbergii (1.23\% in muscle) (Díaz, 2002), and marine decapods such as Homarus gammarus (gonad: 1.5\%; hepatopancreas: $1.7-1.8 \%$; muscle: $1.8-2 \%$ ) and Homarus americanus (gonad: 1.5\%; hepatopancreas: 1.5-1.7\%; muscle: $1.8-1 \%$ ) (Barrento et al., 2009). The high ash levels in storage tissues may be explained by the recognized capacity of crustaceans to accumulate minerals and heavy metals in shell and soft tissues (Meador et al., 1995; MacFarlane et al., 2000) and the high presence of these elements (e.g., boron, copper, chromium, iron, manganese, nickel, selenium, aluminum, arsenic, cadmium, tin, mercury and lead) reported in both Choapa and Limarí rivers (SINIA, 2004a, 2004b).

Concerning proteins, it is known that this macromolecule plays an important role in morphogenesis and energy supply in the embryos of decapods (Rosa \& Nunes, 2003; Luo et al., 2004). In the case of $C$. caementarius, the high levels found in the gonads of mature males and females (up to 50\%), confirm proteins as the main components of gametes in terms of abundance, and also confirm their importance in the synthesis of egg yolk during ovarian development, as occurs in C. quadricarinatus (García-Guerrero et al., 2003) and M. rosenbergii (Revathi et al., 2012). This condition suggests a high demand for proteins during gametogenesis by $C$. caementarius, which is supported evidence that protein required in several crustacean broodstocks for maturation and production of eggs is higher than the level required for growth (Harrison, 1990, 1997).

About total lipids, although these can also accumulate in the gonad and muscle the high levels found in the hepatopancreas of males and females in comparison to the other analyzed tissues, confirm this organ as the main lipid storage place in $C$. caementarius as occurs in other crustaceans (O'Connor \& Gilbert, 1968; Herreid \& Full, 1988; Kucharski \& Da Silva, 1991; Muriana et al., 1993; García et al., 2002). Furthermore, it is generally established in decapods that lipids can act as an energy source for physiological processes such as molting and vitellogenesis, and as the main source of metabolic energy during embryo development (García-Guerrero et al., 2003; Yao et al., 2006; García-Guerrero, 2009). Therefore, the higher levels of total lipids found in the gonads of mature females in comparison to immature females reflect the importance of lipids as an energy source in the eggs of C. caementarius, and suggest an elevated lipid requirement, especially in reproductive females throughout the mating season. This suggestion is in agreement with Harrison (1990), who reported higher lipid requirements for crustacean maturation than for growth and survival, and reinforced by recent studies performed on C. quadricarinatus (Li et al., 2010) and M. rosenbergii (Revathi et al., 2012), where a gradual accumulation of lipids in the ovary was observed during vitellogenesis.

In relation to NFE, the low values found in the gonads of mature animals (male and female) suggest that these compounds have a secondary role in the formation of $C$. caementarius gametes. In contrast, the high levels observed in the hepatopancreas may suggest that NFE is a complementary source of energy that supports, together with lipids, the intense reproductive behavior documented for this species. Viacava et al. (1978) reported daily successive mating events in males because of their polygamous behavior whereas Moreno et al. (2012) reported in females the capacity to remature and have successive spawning events throughout the reproductive season. In addition, these authors also reported in females a molting event performed prior to spawn, which implies a high energy demand.

In some crustaceans as in the case of the crayfish Cherax destructor (Jones \& Obst, 2000) and marine decapods like penaeoideans (Vicent et al., 1988; 
Marangos et al., 1989; Bray \& Lawrence, 1990; Palacios et al., 2000) it has been recognized the capacity to transfer nutrients among tissues to support the high energy demand associated to gonadal maturation. In contrast, studies performed in marine and freshwater species such as Penaeus vannamei (Palacios et al., 2000; Arcos et al., 2003), M. rosenbergii (Cavalli et al., 2001) and A. cinereum and S. reticulatum (Hasek \& Felder, 2005), suggest the possibility of an active mobilization of nutrients from exogenous sources (instead of the hepatopancreas) to obtain energy compounds. In addition, Avarre et al. (2003) also suggested that some yolk nutrients in Penaeus indicus originate from ingested food either directly or after storage in the hepatopancreas.

Although the nutrient mobilization among $C$. caementarius main storage tissues was not directly evaluated in this study, the previously mentioned ability of some crustaceans to use nutrients from exogenous food or stored tissues along with the differences observed in this study between mature and immature animals with regard to the chemical composition of the gonads and the hepatopancreas (Table 1) led us to hypothesize that $C$. caementarius may be able to quickly assimilate and relocate yolk nutrient extracted from storage tissues (mainly hepatopancreas) and/or from exogenous food straight to the ovary to support several mating events in a short time period (Viacava et al.,1978; Moreno et al., 2012). This hypothesis is supported by the condition observed in animals from Limarí River, where immature females showed higher levels of protein and lipids in the hepatopancreas than mature females, while mature females showed higher levels of protein and lipids in the gonads than immature females. This situation may suggest a nutrient mobilization from the hepatopancreas to the ovary during gonadal maturation. On the other hand, the fact that the lipid levels found in the hepatopancreas of mature females from Choapa River were higher than the levels found in immature females, suggest mobilization of lipids to the ovary from exogenous sources instead of hepatopancreas.

This hypothesis must be investigated for males and females in future experiments to properly understand how this species obtains and distributes the energy necessary to support reproductive activity. In summary, this study provides useful information regarding the nutritional requirements of wild $C$. caementarius adults, which can be used by local researchers to improve feeding practices in future activities of reproduction and culture under controlled conditions whether for natural population management or commercial purposes.
In conclusion, the results herein suggest that reproductive behavior and environmental conditions can modify the biochemistry of $C$. caementarius. Nevertheless, the main changes occurs in tissues involved in regulatory processes (the hepatopancreas and the gonads), and to a lesser extent in structural tissues (muscle).

\section{ACKNOWLEDGEMENTS}

We are grateful to Mauricio López Castillo from the Nutrition Laboratory of the Aquaculture Department, Universidad Católica del Norte, for his technical assistance during the chemical analysis. This work was made possible with funding provided by the DGIP Research Program (10301260) of the General Direction of Graduate Research of the Universidad Católica del Norte, Chile.

\section{REFERENCES}

Association of Official Analytical Chemists (AOAC). 1995. Official methods in analysis. The Association of Official Analytical Chemists, Arlington, 1234 pp.

Arcos, F.G., A.M. Ibarra, E. Palacios, C. VazquezBoucard \& I.S. Racotta. 2003. Feasible predictive criteria for reproductive performance of white shrimp Litopenaeus vannamei: egg quality and female physiological condition. Aquaculture, 228: 335-349.

Avarre, J.C., D. Saulnier, Y. Labreuche, D. Ansquer, A. Tietz \& E. Lubzens. 2003. Response of Penaeus indicus females at two different stages of ovarian development to a lethal infection with Vibrio penaeicida. J. Invertebr. Pathol., 82: 23-33.

Bahamonde, N. \& I. Vila. 1971. Sinopsis sobre la biología del camarón de río del norte. Rev. Biol. Pesq. Chile, 5: 3-6.

Barrento, S., A. Marqués, B. Teixeira, P. Vaz-Pires \& M.L. Nunes. 2009. Nutritional quality of the edible tissues of European lobster Homarus gammarus and American lobster Homarus americanus. J. Agric. Food Chem., 57: 3645-3652.

Barrento, S., A. Marqués, B. Teixeira, R. Mendes, N. Bandarra, P. Vaz-Pires \& M.L. Nunes. 2010. Chemical composition, cholesterol, fatty acid and amino acid in two populations of brown crab Cancer pagurus: ecological and human health implications. J. Food Compos. Anal., 23: 716-725.

Benítez-Mandujano, M. \& J. Ponce-Palafox. 2014. Effects of different dietary of protein and lipid levels on the growth of freshwater prawns (Macrobrachium carcinus) broodstock. Rev. MVZ Córdoba, 19(1): 3921-3929. 
Bray, W.A. \& A.L. Lawrence. 1990. Reproduction of eyestalk-ablated Penaeus stylirostris fed various levels of total dietary lipid. J. World Aquacult. Soc., 21: 4152.

Castille, F.L. \& A.L. Lawrence. 1989. Relationship between maturation and biochemical composition of the gonads and digestive glands of the shrimps Penaeus aztecus and Penaeus setiferus (L.). J. Crustacean Biol., 9: 202-211.

Castro, C. 1966. El camarón de río del norte Cryphiops caementarius (Molina). Estud. Oceanol., 2: 11-19.

Cavalli, R., P. Lavens \& P. Sorgeloos. 1999. Performance of Macrobrachium rosenbergii broodstock fed diets with different fatty acid composition. Aquaculture, 179: 387-402.

Cavalli, R., M. Tamtin, P. Lavens \& P. Sorgeloos. 2001. Variations in lipid classes and fatty acid content in tissues of wild Macrobrachium rosenbergii (de Man) females during maturation. Aquaculture, 193: 311324.

Dempson, I.B., C.J. Schwarz, M. Sbears \& G. Furey. 2004. Comparative proximate body composition of Atlantic salmon with emphasis on parr from fluvial and lacustrine habitats. J. Fish Biol., 64: 1257-1271.

Díaz, J. 2002. Deshidratación por aire caliente de músculo de camarón gigante de Malasia (Macrobrachium rosenbergii); Tesis de Ingeniería Agroindustrial, Universidad Nacional de San Martin, Tarapoto, 136 pp.

Ezquerra-Brauer, J.M., N.V. Parra-Vergara \& C. CarrilloPérez. 2003. Efecto de la concentración de proteína en la dieta sobre la calidad química, microbiológica y textura de camarón blanco (Litopenaeus vannamei) cultivado. Biotecnia, 5: 25-33.

García, F., M. González-Baró \& R. Pollero. 2002. Transfer of lipids between hemolymph and hepatopancreas in the shrimp Macrobrachium borellii. Lipids, 37: 581-585.

García-Guerrero, M. 2009. Proximate biochemical variations in eggs of the prawn Macrobrachium americanum (Bate, 1869) during its embryonic development. Aquacult. Res., 40: 575-581.

García-Guerrero, M., H. Villarreal-Colmenares \& I.S. Racotta. 2003. Effect of temperature on lipids, protein, and carbohydrates levels during development from egg extrusion to juvenile stage of Cherax quadricarinatus (Decapoda: Parastacidae). Comp. Biochem. Physiol. A, 135: 147-154.

Harrison, K.E. 1990. The role of nutrition in maturation, reproduction and embryonic development of decapod crustaceans: a review. J. Shellfish Res., 9: 1-28.

Harrison, K.E., 1997. Broodstock nutrition and maturation diets. In: L.R. D'Abramo, D.E. Conklin \& D.M. Akiyama (eds.). Advances in world aquaculture, crustacean nutrition. World Aquaculture Society, Baton Rouge, Louisiana, 6: 390-408.

Hasek, B.E. \& D.L. Felder. 2005. Biochemical composition of ovary, embryo, and hepatopancreas in the grapsoid crabs Armases cinereum and Sesarma $n r$. reticulatum (Crustacea, Decapoda). Comp. Biochem. Physiol. B, 140: 455-463.

Hernández-Vergara, M.P., D.B. Rouse, M.A. OlveraNovoa \& D.A. Davis. 2003. Effects of dietary lipid level and source on growth and proximate composition of juvenile redclaw (Cherax quadricarinatus) reared under semi-intensive culture conditions. Aquaculture, 223: 107-115.

Herreid, C.F. \& R.J. Full. 1988. Energetics and locomotion. In: B. Macmahon (ed.). Biology of land crabs. Cambridge University Press, Cambridge, pp. 337-377.

Huner, J.V. \& O.V. Lindqvist. 1985. Exoeskeleton mineralization in astacid and cambarid crayfishes (Decapoda, Crustacea). Comp. Biochem. Physiol. A, 80(4): 515-521.

Huner, J.V., O.V. Lindqvist \& H. Könönen. 1988. Comparison of morphology and edible tissues of two important commercial crayfishes, the noble crayfhis, Astacus astacus Linné and the red swamp crayfish, Procambarus clarkia (Girard) (Decapoda, Astacidae and Cambaridae). Aquaculture, 68: 45-47.

Jara, C.G., E.H. Rudolph \& E.R. González. 2006. Estado de conocimiento de los malacostráceos dulceacuícolas de Chile. Gayana, 70: 40-49.

Jones, P.L. \& J.H. Obst. 2000. Effects of starvation and subsequent refeeding on the size and nutrient content of the hepatopancreas of Cherax destructor (Decapoda: Parastacidae). J. Crustacean Biol., 20: 431-441.

Kucharski, L.C.R. \& R.S.M. Da Silva. 1991. Seasonal variation on the energy metabolism in an estuarine crab, Chasmagnathus granulata (Dana, 1851). Comp. Biochem. Physiol. A, 100: 599-602.

Li, J., Z. Guo, X. Gan, Q. Wang \& Y. Zhao. 2010. Biochemical changes during vitellogenesis in the red claw crayfish, Cherax quadricarinatus (von Martens). Aquacult. Res., 41: 446-455.

Luo, W., Z.L. Zhou, Y.L. Zhao, Z.B. Yang \& M.F. Zhang. 2004. Analysis on the contents of protein and amino acids in Cherax quadricarinatus during different embryonic development stages (Chinese). J. East China Norm. Univ., Nat. Sci., 1: 88-92.

MacFarlane, G.R., D.J. Booth \& K.R. Brown. 2000. The semaphore crab Heloecious cordiformis: bioindication potential of heavy metals in estuarine systems. Aquat.Toxicol., 50: 153-166.

Marangos, C., L. Ramos \& M. Oliva. 1989. Variations des teneurs en protéines de 1'hemolymphe, de l'hépato- 
pancréas et de l'ovaire de Penaeus schmitti au cours de la maturation ovarienne (Crustacea, Decapoda, Penaeidae). Arch. Int. Physiol. Biochim., 96: 179-190.

Meador, J.P., J.E. Stein, W.L. Reichert \& U. Varanasi. 1995. A review of bioaccumulation of polycyclic aromatic hydrocarbons by marine organisms. In: G.W. Ware (ed.). Reviews of environmental contamination and toxicology. Springer-Verlag, NewYork, pp. 79165.

Meruane, J.A., C. Morales, C. Galleguillos, M. Rivera \& H. Hosokawa. 2006. Experiencias y resultados de investigaciones sobre el camarón de río del norte Cryphiops caementarius (Molina, 1782) (Decapoda: Palaemonidae): historia natural y cultivo. Gayana, 70: 280-292.

Moreno, J.E., C.A. Méndez, J.A. Meruane \& M.C. Morales. 2012. Descripción histológica y caracterización de los estados de madurez gonadal de hembras de Cryphiops caementarius (Molina 1782) (Decapoda: Palaemonidae). Lat. Am. J. Aquat. Res., 40: 668-678.

Muriana, F.J.G., V. Ruiz-Gutierrez, M.L. GallardoGuerrero \& M.L. Minguez-Mosquera. 1993. A study of the lipids and carotenoprotein in the prawn Penaeus japonicus. J. Biochem., 114: 223-229.

Norambuena, R. 1977. Antecedentes biológicos de Cryphiops caementarius (Molina, 1782) en el estero "El Culebrón" (Crustacea, Decapoda, Palaemonidae). Biol. Pesq. Chile, 9: 7-19.

O'Connor, J.D. \& L.I. Gilbert. 1968. Aspects of lipid metabolism in crustaceans. Am. Zool., 8: 529-539.

Oliveira, G.T., F.A. Fernandes, G. Bond-Buckup, A.A. Bueno \& R.S.M. Silva. 2003. Circadian and seasonal variations in the metabolism of carbohydrates in Aegla ligulata (Crustacea: Anomura: Aeglidae). Mem. Natl. Mus. Victoria, Melbourne, 60: 59-62.

Oliveira, G.T., F.A. Fernandes, A.A. Bueno \& G. BondBuckup. 2007. Seasonal variations in the intermediate metabolism of Aegla platensis (Crustacea, Aeglidae). Comp. Biochem. Physiol. A, 147: 600-606.

Palacios, E., A.M. Ibarra \& I.S. Racotta. 2000. Tissue biochemical composition in relation to multiple spawning in wild and pond-reared Penaeus vannamei broodstock. Aquaculture, 185: 353-371.

Pillay, K.K. \& N.B. Nair. 1973. Observations on the biochemical changes in gonads and other organs of Ucaa nnulipes, Portunus pelagicus and Metapenaeus affinis (Decapoda: Crustacea) during the reproductive cycle. Mar. Biol., 18: 167-198.

Ramírez, E., A. Silva, M. Guevara, M. Núñez, R. Bauzá \& B. Arredondo-Vega. 2010. Composición bioquímica del camarón dulceacuícola Macrobrachium jelskii (Miers, 1877) sometido a condiciones de cultivo. Zootec. Trop., 28(1): 65-72.

Revathi, P., P. Iyapparaj, N. Munuswamy \& M. Krishnan. 2012. Vitellogenesis during the ovarian development in freswater female prawn Macrobrachium rosenbergii (De Man). Int. J. Aquat. Sci., 3(2): 13-27.

Rivera, M. \& J. Meruane. 1994. Evaluación y manejo de las poblaciones de camarón de río en la IV Región. CORFO-FONTEC, Informe Final, 28 pp.

Rodríguez-González, H., A. Hernández-Llamas, H. Villarreal, P.E. Saucedo, M. García-Ulloa \& C. Rodríguez-Jaramillo. 2006. Gonadal development and biochemical composition of female crayfish Cherax quadricarinatus (Decapoda: Parastacidae) in relation to the gonadosomatic index at first maturation. Aquaculture, 254: 637-645.

Rojas, R., M.C. Morales, M.M. Rivadeneira \& M. Thiel. 2012. Male morphotypes in the Andean river shrimp Cryphiops caementarius (Decapoda: Caridea): morphology, coloration and injuries. J. Zool., 288: 2132.

Rosa, R.A. \& M.L. Nunes. 2002. Biochemical changes during the reproductive cycle of the deep-sea decapod Nephrops norvegicus on the south coast of Portugal. Mar. Biol., 141: 1001-1009.

Rosa, R.A. \& M.L. Nunes. 2003. Biochemical composition of deep-sea decapod crustaceans with two different benthic life strategies of the Portuguese south coast. Deep-Sea Res., 50: 119-130.

Santos, F.L., V.B. Azeredo \& A.S. Martins. 2007. Effect of supplying food complemented with linseed on the chemical composition of Malaysian shrimp (Macrobrachium rosenbergii). Cienc. Tecnol. Alimentos, 27(4): 851-855.

Saravana-Bhavan, P., S. Radhakrishnan, C. Seenivasan, R. Shanti, R. Poongodi \& S. Kannan. 2010. Proximate composition and profiles of amino acids and fatty acids in the muscle of adult males and females of commercially viable prawn species Macrobrachium rosenbergii collected from natural culture environments. Int. J. Biol., 2(2): 107-119.

Schirf, V.R., L.S. Turner, C. Hanapel, P. De La Cruz \& P.F. Dehn. 1987. Nutritional status and energy metabolism of crayfish (Procambarus clarkii, Girardi) muscle and hepatopancreas. Comp. Biochem. Physiol. A, 88: 383-386.

Sistema Nacional de Información Ambiental (SINIA). 2004a. Diagnóstico y clasificación de los cursos y cuerpos de agua según objetivos de calidad: cuenca del río Choapa. Ministerio de Obras Públicas, Santiago, $131 \mathrm{pp}$. 
Sistema Nacional de Información Ambiental (SINIA). 2004b. Diagnóstico y clasificación de los cursos y cuerpos de agua según objetivos de calidad: cuenca del río Limarí. Ministerio de Obras Públicas, Santiago, 137 pp.

Sokal, R.R. \& F.J. Rohlf. 1981. Biometry: the principles and practice of statistics of biological research. W.H. Freeman \& Co., San Francisco, 859 pp.

Tacon, A.G.J. 1989. Nutrición y alimentación de peces y camarones cultivados. Manual de Capacitación. Organización de las Naciones Unidas para la Agricultura y la Alimentación. FAO, Roma, 592 pp.

Viacava, M., R. Aitken \& J. Llanos. 1978. Estudio del camarón en el Perú. Bol. Inst. Mar del Perú, 3: 165232.

Vicent, M., L. Ramos \& M. Oliva. 1988. Variations qualitatives et quantitatives des pigments caroténoides dans l'ovaire, et l'hépatopancréas de Penaeus schmitti au cours de la maturation ovarienne. Arch. Int. Physiol. Biochim., 96: 155-164.

Received: 4 September 2014; Accepted: 23 June 2015
Vinagre, A.S., A.P.N. Amaral, F.P. Ribarcki, E.F. Silveira \& E. Périco. 2007. Seasonal variation of energy metabolism in ghost crab Ocypode quadrata at Siriú Beach (Brazil). Comp. Biochem. Physiol. A, 146: 514519.

Wen, X., L. Chen, C. Ai, Z. Zhou \& H. Jiang. 2001. Variation in lipid composition of Chinese mittenhanded crab, Eriocheir sinensis during ovarian maturation. Comp. Biochem. Physiol. B, 130: 95-104.

Yao, J.J., Z. Yun-long, Q. Wang, Z. Zhong-liang, H. XianCheng \& D.A. Xiao-Wei. 2006. Biochemical compositions and digestive enzyme activities during the embryonic development of prawn Macrobrachium rosenbergii. Aquaculture, 253: 573-582. 